\title{
Cascading bedpans and dodgy MOTs
}

In a recent speech health secretary Alan Johnson quoted his illustrious predecessor Aneurin Bevan, the post-war founder of the NHS, who famously declared his objective that 'if a bedpan is dropped on a hospital floor in Tredegar (his South Wales constituency), its noise should resound in the Palace of Westminster'. Johnson bemoaned the 'monolithic centralism' that developed over subsequent decades, apparently oblivious to the consolidation of this monolith over 10 years of New Labour. The deployment of bedpans in every hospital in the country is now the sort of NHS activity that is governed by some target or performance indicator accessible to any 'choose and book' customer.

Whereas Bevan faced fierce medical and political opposition, Johnson faces little resistance to his drive to regulate the day-to-day activities of NHS staff. Hence new initiatives from Whitehall now cascade through the health service like the contents of an upturned bedpan.

Take the introduction of 'extended opening hours' in general practice. This policy was hastily adopted by Gordon Brown last summer in an attempt to provide a distinctive popular element in his lacklustre leadership campaign. Within a few months, the BMA has been comprehensively outmanoeuvred (admittedly not a difficult task), the PCTs have rolled over (again par for the course) and GPs will soon be forced to move ever closer to Tesco opening hours. It is already clear that the government's populist gesture to the focus groups will be met by equally cynical adjustments in surgery hours, which may tick the boxes but will not improve services. Such bad faith, New Labour's distinctive contribution to the health service, is more corrosive to the spirit of the NHS than any expenditure cuts.

While there has been some protest over 'extended hours', and also over the accelerated privatisation of inner city surgeries, the plan to introduce 'health MOTs' for the over 40s has provoked little criticism. Yet this policy - announced by the health minister in April - is likely to be the most damaging of all.

When cardiovascular risk screening in primary care was first proposed under the National Service Framework for Coronary Heart Disease in the early 2000s, Rouse and Adab, in this journal, pointed out that the proposals did not meet established criteria for a population screening programme. ${ }^{1}$ They argued that the benefits of population cardiovascular screening must be established through properly conducted trials and that, if such a programme was to be introduced, adequate resources and management structures must first be identified. ${ }^{2}$ None of these requirements has been met.

Others pointed out the adverse effects of 'labelling and anxiety', observing that while screening may benefit populations, only a few individuals would benefit and some may even be harmed. ${ }^{3}$

The very popularisation of the notion of a 'health MOT' is curious. Readers of a certain age will recall that in 1960 the old 'Ministry of Transport' introduced a test of safety and roadworthiness for all vehicles more than 10 years old. At the dawn of the age of the motorway, the object of the MOT was to push old cars off the road (and stimulate some demand for the new products of the British motor industry).

Although the aim of the health MOT is to prevent disease (or at least to detect it early), it may well have the effect of encouraging people who considered themselves well to accept a new identity as being 'at risk' of heart attack or stroke. If they then seek long-term incapacity benefit they may find themselves the targets of another government initiative to drive them back to work. They may then be obliged to seek out the medical equivalent of the 'dodgy MOT': perhaps these will be provided by GPs working 'extended hours' in a supermarket garage.

\section{REFERENCES}

1. Rouse A, Adab P. Is population coronary heart disease screening justified? A discussion of the National Service Framework for coronary heart disease (Standard 4). Br J Gen Pract 2001; 51 : 834-837.

2. Holland WH, Stewart S. Screening in disease prevention: what works? (European Observatory on Health Systems and Policies). Radcliffe publishing: Oxford, 2005

3. Martineau TM, Kinmouth AL. Screening for cardiovascular risk: public health imperative or matter for individual informed choice? BMJ 2002 325: 78-80.

DOI: 10.3399/bjgp08X299173

\section{Top Tips in 2 minutes}

Mary Quant said 'A woman is as young as her knees.' George Clooney has been heard to say 'Things hurt me now. My knees hurt, my back hurts. But your head still thinks it's 23.' Are beautiful knees more durable than those less aesthetically pleasing? ... but back in the real world.

How good are yours, and your patients? It seems that we are all noticing changes more quickly and expecting action from the medics in order to stay young and active. The increasing number of knee replacements suggests that we are reaching the end game too quickly.

A recent survey (October 2007) of orthopaedic surgeons undertaken at the British Orthopaedic Association Congress indicates that the average patient undergoing hip or knee joint replacement is now clinically obese and significantly younger than 10 years ago.

So how can we help in primary care, to assess and improve lives before the knife and keep those knees supple enough for anything? And what can we check to ensure it is just wear and tear - what examination and tests help, and how do we keep going with peak performance?

In the words of Mae West, it takes two to get one into trouble - so make sure you look after them both.

\section{Ruth Bastable, Sarah Rann and Vinny Barker}

\section{Acknowledgements}

Thanks to Addenbrookes postgraduate medical centre for advice, support and good humour.

More top tips can be found at: http://www.addenbrookespgmc.org.uk/courses.asp DOI: 10.3399/bjgp08X299182 


\section{Top Tips in 2 minutes: Osteoarthritis in the knee.}

\begin{tabular}{|c|c|}
\hline Why: & $\begin{array}{l}\text { Very common in aging population with high expectations } \\
40000 \text { UK knee replacements per year, set to double in } 10 \text { years time }\end{array}$ \\
\hline How: & $\begin{array}{l}\text { History } \\
\text { - Pain, swelling; mechanical symptoms: locking, giving way } \\
\text { - Sleep disturbance and walking tolerance; quality of life } \\
\text { Examination } \\
\text { - Swelling: exclude inflammatory cause; deformity: deteriorating valgus likely to need surgery } \\
\text { - Focal tenderness: medial and patello-femoral more likely to respond to non-operative measures } \\
\text { - Gait: severe osteoarthritis with poor mobility has worse outcome with joint replacement: } \\
\text { - Don't leave surgery too late } \\
\text { Investigation } \\
\text { - Blood tests to exclude inflammatory arthritis if concerned +/- aspirate } \\
\text { - X-ray: weight bearing +/- Tunnel (for loose bodies) and 'skyline' patella (this is axial view through } \\
\text { the patello-femoral joint, combined with the lateral it gives the two orthogonal views necessary to } \\
\text { interpret the patello-femoral joint) } \\
\text { - Possible MRI: If early osteoarthritis to exclude meniscus tear }\end{array}$ \\
\hline What next and when: & $\begin{array}{l}\text { GP treatment } \\
\text { - If overweight: weight loss, exercise: (non impact), analgesia: NSAID, glucosamine ( } 1.5 \mathrm{~g} / \text { day) } \\
\text { If fails consider physiotherapy: } \\
\text { - Guided exercises - especially for patello-femoral problem } \\
\text { - Knee brace - medial offload knee brace in medial osteoarthritis (this brace pushes the knee into } \\
\text { valgus to ensure maximal weight goes through the less arthritic lateral compartment) } \\
\text { - Walking aid } \\
\text { If fails consider orthopaedic surgical opinion: } \\
\text { - Out patient viscosupplimentation: Hylan G-F } 20 \\
\text { - Arthroscopy, and debridement } \\
\text { When symptoms worse than radiographs and some cartilage is preserved (implies likely cartilage flap/tear); } \\
\text { - Osteotomy } \\
\text { - Young patient with heavy work (demands would cause rapid wear of artifical joint); } \\
\text { - Patello-femoral replacement } \\
\text { - Total knee replacement } \\
\text { Excellent long-term results for severe osteoarthritis in patients over } 55 \text { years } \\
\text { Over } 90 \% \text { of replacement sound at } 10 \text { years }\end{array}$ \\
\hline Patient information: & $\begin{array}{l}\text { Useful web links for patients: http://www.patient.co.uk/showdoc/1365 } \\
\text { Arthritis Research Campaign: osteoarthritis of the knee (printable information booklet): } \\
\text { http://www.arc.org.uk/arthinfo/patpubs/6027/6027.asp } \\
\text { Arthritis Research Campaign: a new knee joint (printable information booklet): } \\
\text { http://www.arc.org.uk/arthinfo/patpubs/6021/6021.asp }\end{array}$ \\
\hline References/Web links: & $\begin{array}{l}\text { Home-based exercise programme for knee pain and knee osteoarthritis: randomised controlled trial. } \\
\text { BMJ 2002; 325: 752. http://www.bmj.com/cgi/content/abstract/325/7367/752 } \\
\text { Is glucosamine worth taking for osteoarthritis? Drug Ther Bull 2002; 40: 81-83 } \\
\text { http://www.dtb.bmj.com/ }\end{array}$ \\
\hline Who are you: & Mr P Julian Owen, consultant trauma and orthopaedic surgeon, Addenbrooke's Hospital, Cambridge \\
\hline Date: & February 2008 \\
\hline
\end{tabular}

